\title{
Temperature modulation of the activity and malate inhibition of the phosphoenolpyruvate carboxylase from leaves of Alternanthera pungens, compared to that of Lycopersicom esculentum
}

\author{
${\text { Bhaskarrao Chinthapalli, }{ }^{1} \text {, D. S. Vijaya Chitra }}^{1}$, Agepati S. Raghavendra ${ }^{2}$ \\ ${ }^{1}$ Department of Biology, College of Natural Sciences, Arba Minch University, Arba Minch, P.O. Box 21, Ethiopia \\ ${ }^{2}$ Department of Plant Sciences, School of Life Sciences, University of Hyderabad, Prof. C.R Rao Road, Gachibowli, Hyderabad 500 046 , \\ Andhra Pradesh, India
}

Email address:

chinthapalli.bhaskar@amu.edu.et (B. Chinthapalli)

\section{To cite this article:}

Bhaskarrao Chinthapalli, D. S. Vijaya Chitra, Agepati S. Raghavendra. Temperature Modulation of the Activity and Malate Inhibition of the Phosphoenolpyruvate Carboxylase from Leaves of Alternanthera pungens, Compared to that of Lycopersicom esculentum. American Journal of BioScience. Vol. 2, No. 6, 2014, pp. 238-243. doi: 10.11648/j.ajbio.20140206.18

\begin{abstract}
Temperature caused marked modulation of phosphoenolpyruvate carboxylase (PEPC, EC 4.1.1.31) in leaf discs of Alternanthera pungens $\left(\mathrm{C}_{4}\right.$ plant) as well as Lycopersicon esculentum $\left(\mathrm{C}_{3}\right.$ species). The optimal incubation temperature for PEPC activity in A. pungens was $45^{\circ} \mathrm{C}$ compared to $30{ }^{\circ} \mathrm{C}$ in L. esculentum. A. pungens lost nearly $61 \%$ of PEPC activity on exposure to a low temperature of $15{ }^{\circ} \mathrm{C}$, compared to only about a $33 \%$ loss in the case of L. esculentum. The $\mathrm{C}_{4}$ enzyme was less sensitive to supra-optimal temperature and more sensitive to sub-optimal temperature than that of the $\mathrm{C}_{3}$ species. Further as the temperature was raised from $15{ }^{\circ} \mathrm{C}$ to $50{ }^{\circ} \mathrm{C}$, there was a sharp decrease in malate sensitivity of PEPC. The extent of such a decrease in $\mathrm{C}_{4}$ plants was more than that in $\mathrm{C}_{3}$ species. Arrhenius plots that were constructed by plotting the activity of PEPC against the reciprocal of temperature in the absence or presence of malate exhibited abrupt changes or "break-points" at only one point of $17^{\circ} \mathrm{C}$ in A. pungens while at two points corresponding $17^{\circ} \mathrm{C}$ and $27^{\circ} \mathrm{C}$ in case of L. esculentum. The activation energy of PEPC from A. pungens was less compared to that of L. esculentum in the temperature range of 10 to $27^{\circ} \mathrm{C}$. However, the activation energy of PEPC from A. pungens was less than that of L. esculentum above the temperature of $27^{\circ} \mathrm{C}$. The activation energy increased by 2 to 4 fold at temperatures below $17^{\circ} \mathrm{C}$, in case of both $A$. pungens and L. esculentum. Thus, our results show the activity and malate sensitivity of PEPC can be influenced in relation to high temperature tolerance of $\mathrm{C}_{4}$ plants, which can be physiologically significant.
\end{abstract}

Keywords: Temperature, Malate Sensitivity, Cold Sensitivity, PEPC, Arrhenius Plots, Activation Energy

\section{Introduction}

Phosphoenolpyruvate carboxylase (PEPC, EC 4.1.1.31) which catalyses the primary step of phosphoenolpyruvate (PEP) carboxylation in $\mathrm{C}_{4}$ and CAM plants, is regulated by internal metabolites, its common inhibitor being malate and its activator glucose-6-phosphate (Glu-6-P). Stupendous progress has been made in our knowledge of biochemistry and molecular biology of PEPC in not only $\mathrm{C}_{4}$ plants, but also $\mathrm{C}_{3}$ species and legume root nodules. Several authors have periodically reviewed the literature on the properties, regulation and functions of $\mathrm{C}_{4}$ PEPC particularly in the past decade [1-10].
$\mathrm{C}_{4}$ plants differ from $\mathrm{C}_{3}$ plants in several features, including their light and temperature responses [11, 12]. The temperature optima for photosynthesis and growth in $\mathrm{C}_{4}$ plants are usually higher than those for $C_{3}$ plants [13]. However, the $\mathrm{C}_{4}$ plants are quite sensitive to cold temperatures. The cold sensitivity $\mathrm{C}_{4}$ pathway has been suggested to be related to the cold sensitivity of key $\mathrm{C}_{4}$ enzymes, such as pyruvate phosphate dikinase (PPDK) or PEPC [14-16].

The cold sensitivity of PPDK in $\mathrm{C}_{4}$ plants is well established and the mechanism of cold inactivation of PPDK is studied in detail [15, 17-18]. In contrast, the reports on cold sensitivity of PEPC have been quite conflicting. There 
are reports which suggest PEPC is sensitive to cold temperature $[19,20]$, while others could not detect any significant change in the properties of PEPC at cold temperature [18, 21]. Further, some of these experiments involved either long term exposures of plants or short term exposure of purified enzymes and thus involved diverse experimental material.

On illumination, the activity of PEPC is enhanced by 2-3 fold along with a marked decrease in the malate sensitivity of the enzyme. These changes during the light activation are due to mainly the phosphorylation of the enzyme [3, 22-23]. Despite being a cytosolic enzyme, the $\mathrm{C}_{4}$ PEPC is modulated markedly by light as well as temperature. The individual effects of either temperature or light on the activity and regulatory properties of $\mathrm{C}_{4}$ PEPC have been studied extensively [24-26]. However, there are only a few reports on the interactive influence of light and temperature on $\mathrm{C}_{4}$ PEPC $[20,27]$. The interaction between light and temperature while modulating both the activity and regulatory properties of PEPC in leaf discs and leaves of Amaranthus hypochondriacus has recently been reported [28]. Earlier studies were carried out in vitro. Compared to the available literature on the properties and mechanism of light activation of PEPC, in $\mathrm{C}_{4}$ plants, the literature on the regulation by temperature of PEPC is quite limited [2]. The present study is an attempt to characterize the temperature responses of PEPC from a typical $\mathrm{C}_{4}$ plant, Alternanthera pungens and compare with that of a $\mathrm{C}_{3}$ plant, Lycopersicon esculentum. Experiments were conducted on leaf discs so as to simulate physiological situation in vivo. The results indicate that the changes in kinetic and regulatory properties of PEPC are examine critically with temperature changes encountered by $\mathrm{C}_{4}$ and $\mathrm{C}_{3}$ species.

\section{Materials and Methods}

\subsection{Plant Material and Growth Conditions}

Plants of Alternanthera pungens H.B.K ( $\mathrm{C}_{4}$ plant) was propagated by transplantation of cuttings and Lycopersicon esculentum Mill $\left(\mathrm{C}_{3}\right.$ species $)$ were raised from seeds. The plants were grown in earthen pots filled with soil supplemented with farmyard manure. They were grown outdoors in the field, in the campus of the University of Hyderabad under a natural photoperiod of approximately 12 $\mathrm{h}$ and temperatures of $30-40{ }^{\circ} \mathrm{C}$ day/25-30 ${ }^{\circ} \mathrm{C}$ night. The upper fully expanded leaves were harvested, about 2-3 $\mathrm{h}$ after sunrise. Leaf discs (each of $c a .0 .2 \mathrm{~cm}^{2}$ ) were prepared from 4- to 6- week-old plants of Alternanthera pungens and 2- to 4-week-old plants of Lycopersicon esculentum.

\subsection{Extraction and Assay of PEPC}

The extraction and assay of PEPC were conducted following the standard method previously described [24, 23]). The temperature range tested in $A$. pungens $\left(\mathrm{C}_{4}\right.$ plant $)$ was $15^{\circ} \mathrm{C}$ to $55^{\circ} \mathrm{C}$ and for L. esculentum $\left(\mathrm{C}_{3}\right.$ species) was $15^{\circ} \mathrm{C}-$ $50^{\circ} \mathrm{C}$. Thirty leaf discs (each of $c a .0 .2 \mathrm{~cm}^{2}$ and a total weight of $125 \mathrm{mg}$ ) were extracted in a chilled mortar and pestle with $500 \mathrm{ml}$ of extraction medium containing $100 \mathrm{mM}$ TRIS-HCl (pH 7.3), $10 \mathrm{mM} \mathrm{MgCl} 2,2 \mathrm{mM} \mathrm{K} \mathrm{HPO}_{4}, 1 \mathrm{mM}$ EDTA, $10 \%$ (v/v) glycerol, $10 \mathrm{mM} \beta$-mercaptoethanol, $10 \mathrm{mM} \mathrm{NaF,} 2$ $\mathrm{mM}$ phenylmethylsulphonyl fluoride (PMSF), $10 \mathrm{mg} \mathrm{ml}^{-1}$ chymostatin was used, instead of PMSF. However, PMSF was used routinely, as it was found to be quite effective in avoiding proteolysis in the case of $A$. pungens. The homogenate was centrifuged at $15000 \mathrm{~g}$ for $5 \mathrm{~min}$ and the supernatant was used as 'crude extract'. A small aliquot was kept aside, prior to centrifugation, for chlorophyll estimation.

Maximum PEPC activity was assayed by coupling to NAD-malate dehydrogenase (NAD-MDH) and monitoring NADH oxidation at $340 \mathrm{~nm}$ in a Shimadzu $1601 \mathrm{UV}-$ Visible spectrophotometer at a temperature of $30{ }^{\circ} \mathrm{C}$. The assay mixture $(1 \mathrm{ml})$ contained $50 \mathrm{mM}$ TRIS- $\mathrm{HCl}(\mathrm{pH} 7.3), 5 \mathrm{mM}$ $\mathrm{MgCl}_{2}, 0.2 \mathrm{mM} \mathrm{NADH}, 2 \mathrm{U}$ of NAD-MDH, $2.5 \mathrm{mM}$ PEP, $0.05 \mathrm{mM} \mathrm{NaHCO}$, and leaf extract equivalent to $1 \mu \mathrm{g}$ of chlorophyll. The sensitivity of PEPC to malate was checked by adding malate to make a final concentration of $0.5 \mathrm{mM}$ in the assay mixture. Each assay was done in triplicate for each sample.

\subsection{Incubation of Leaf Discs at Different Temperature}

Thirty leaf discs were floated on distilled water in a $5 \mathrm{~cm}$ diameter Petri dishes and were left in darkness for $2 \mathrm{~h}$. After predarkening, the leaf discs were incubated $30 \mathrm{~min}$ at required temperature in the range of $15^{\circ} \mathrm{C}$ to $50^{\circ} \mathrm{C}$ in a themo-statically controlled water bath. At the end of $30 \mathrm{~min}$ in each temperature, the leaf discs were extracted (as described above) and the extract was examined for PEPC activity.

\subsection{Estimation of Chlorophyll}

Chlorophyll was estimated by extraction with $80 \%$ (v/v) acetone [29].

\subsection{Replications and Statistical Analysis}

All experiments were repeated 3 to 5 times on different days. The average values $\pm \mathrm{SE}$ are presented. Statistical analysis of the data was done using the software Sigmaplot (version 10.0).

\section{Results}

The optimal temperature for PEPC activity in leaf discs of A. pungens was $45^{\circ} \mathrm{C}$ compared to $30^{\circ} \mathrm{C}$ in L. esculentum (Figure 1 (a)). The response of enzyme to temperature was quite dramatic when plotted as the \% of maximum activity (Figure 1 (b)). The decrease at $40^{\circ} \mathrm{C}$ was much higher in case of $L$. esculentum than that of $A$. pungens. Similarly the decrease in activity of PEPC at temperatures above $15^{\circ} \mathrm{C}$ was much greater in the case of $A$. pungens than that in $L$. esculentum. Thus, the $\mathrm{C}_{4} \mathrm{PEPC}$ was less sensitive to supraoptimal temperatures and more sensitive to sub-optimal temperatures than that of $\mathrm{C}_{3}$ species. As the temperature was 
raised from $15{ }^{\circ} \mathrm{Cto50}{ }^{\circ} \mathrm{C}$, there was a sharp decrease in malate sensitivity of PEPC. The extent of such a decrease in $\mathrm{C} 4$ plants was more than that in $\mathrm{C} 3$ species when the enzyme was assayed at $0.05 \mathrm{mM}$ bicarbonate (Figure 1 (c)). The extent of malate inhibition was always higher in case of $L$. esculentum than that of $A$. pungens.

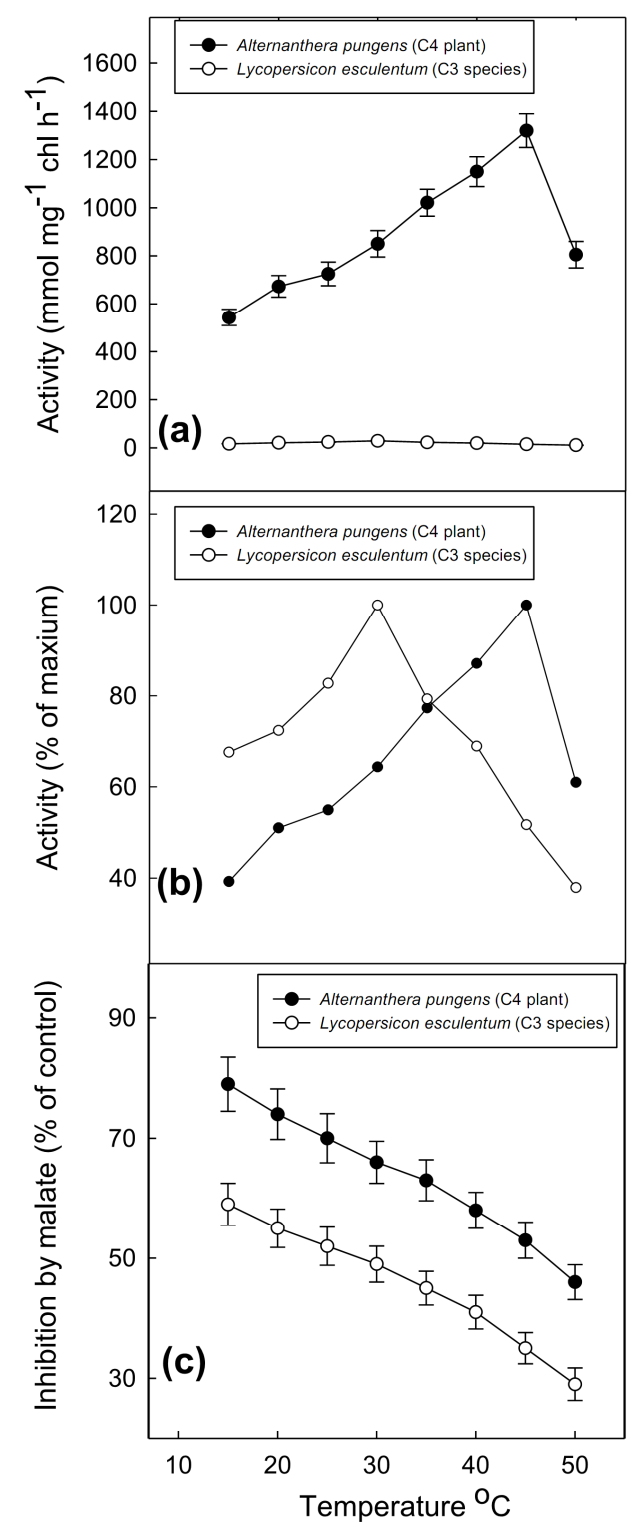

Figure 1. The activity of PEPC in extracts from leaf discs of Alternanthera pungens $\left(C_{4}\right.$ plant) and Lycopersicon esculentum $\left(C_{3}\right.$ species) after exposure to varying temperatures. (a) The activity of PEPC is represented as either enzyme units of $\mu \mathrm{mol} \mathrm{mg}^{-1} \mathrm{Chl} \mathrm{h} \mathrm{h}^{-1}$ (b) or \% of its maximum. The activity of PEPC in extracts from leaf discs of Alternanthera pungens $\left(C_{4}\right.$ plant) and Lycopersicon esculentum ( $C_{3}$ species) after exposure to varying temperatures. The preincubation time for leaf discs was 30 min for each temperature. The experiments were done on at least three different days and the average values $\pm S E$ are represented. The maximal activity of PEPC in A. pungens and L. esculentum were $1273 \pm 98$ and $29.4 \pm 2.4 \mu \mathrm{mol} \mathrm{mg}{ }^{-1} \mathrm{Chl} \mathrm{h}{ }^{-1}$, respectively. (c) Effect of temperature on the malate sensitivity of PEPC in extracts prepared from the leaf discs of Alternanthera pungens $\left(C_{4}\right.$ plant) or L. esculentum $\left(C_{3}\right.$ species), exposed to different temperatures. The activity was measured at $30^{\circ} \mathrm{C}$ and assayed in the absence or presence of either 0.5 $\mathrm{mM}$ malate (A. pungens) or $2 \mathrm{mM}$ malate (L. esculentum). Further details were as described in figure $1 b$.
Arrhenius plots were constructed by plotting the activity of PEPC against the reciprocal of temperature in the absence (Figure 2 (a)) or presence of malate (Figure 2 (b)). These enzyme activities were measured after exposing the leaf discs to a range of $10^{\circ} \mathrm{C}$ to $45^{\circ} \mathrm{C}$ in case of $A$. pungens and $10^{\circ} \mathrm{C}$ to $35^{\circ} \mathrm{C}$ in case of $L$. esculentum. Arrhenius plots exhibited abrupt changes or "break-points" at only one point of $17^{\circ} \mathrm{C}$ in A. pungens $\left(\mathrm{C}_{4}\right)$ while at two points corresponding $17^{\circ} \mathrm{C}$ and $27^{\circ} \mathrm{C}$ in case of L. esculentum $\left(\mathrm{C}_{3}\right)$. The patterns of Arrhenius curves in presence of malate were quite similar to those in the absence, with similar breaks in the slope.

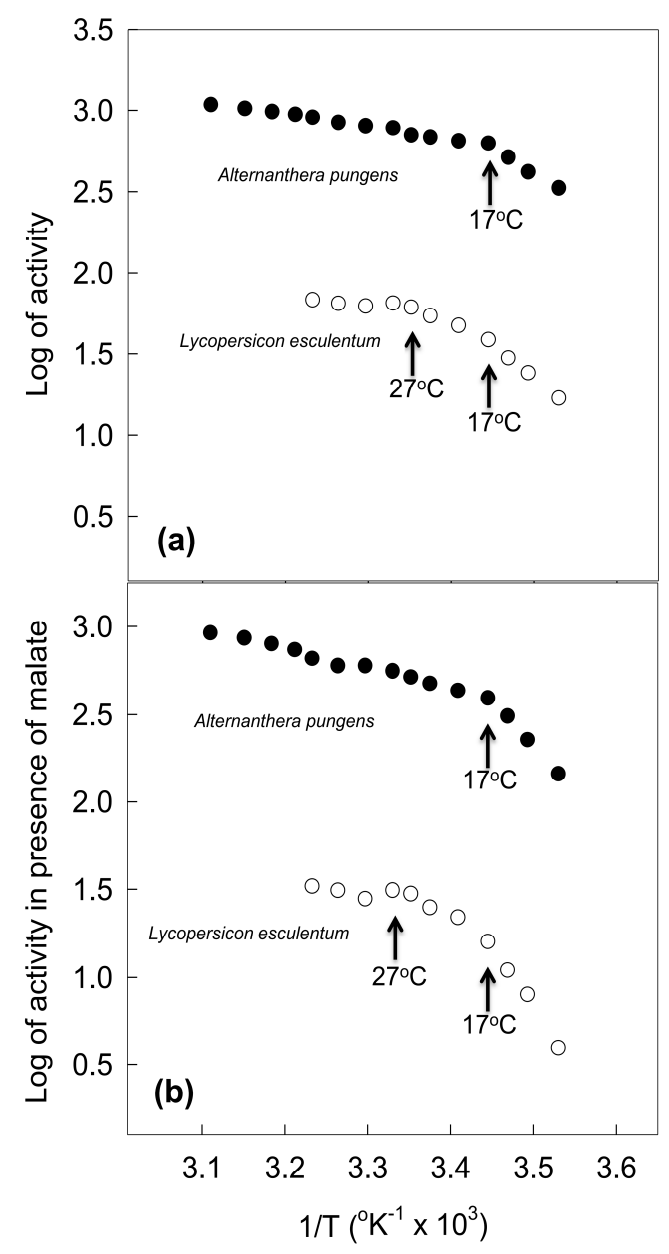

Figure 2. Arrhenius plots of PEPC activity in the absence of malate or in the presence of malate during the assay. The points are averages of three to five seperate experiments. The activity of PEPC was determined in the extracts prepared from leaf discs of Alternanthera pungens $\left(C_{4}\right.$ plant $)$ or Lycopersicon esculentum ( $C_{3}$ species), exposed to varying temperatures. Further details were as in Figure 1. The 'break-points' are indicated by arrows.

The activation energy of PEPC from A. pungens was less than that from $L$. esculentum in the temperature range of 10 to $27^{\circ} \mathrm{C}$ (Table 1). However, the activation energy of PEPC from A. pungens was less compared to L. esculentum above the temperature of $27^{\circ} \mathrm{C}$. The activation energy increased by 2 to 4 fold at temperatures below $17^{\circ} \mathrm{C}$, in case of both $A$. pungens $\left.\mathrm{C}_{4}\right)$ and L. esculentum $\left(\mathrm{C}_{3}\right)$. 


\section{Discussion}

The temperature can cause quite striking changes in not only the activity but also the regulatory properties of PEPC in both $\mathrm{C}_{3}$ and $\mathrm{C}_{4}$ plants. The optimal temperature for PEPC in A. pungens $\left(\mathrm{C}_{4}\right)$ was $45^{\circ} \mathrm{C}$ compared to $30^{\circ} \mathrm{C}$ in $L$. esculentum $\left(\mathrm{C}_{3}\right.$ species) is not surprising (Figure 1). The activities of PEPC and NADP-ME in desalted extracts from different species of sugarcane showed no large changes after incubating the enzyme at various temperatures from $30^{\circ} \mathrm{C}$ to $0^{\circ} \mathrm{C}$ [16]. In contrast, PEPC in extracts of $P$. maximum lost up to $50 \%$ of its activity after incubation for $60 \mathrm{~min}$ at $0^{\circ} \mathrm{C}$ while the enzyme from $P$. miliaceum was stable [21]. Our results confirm that the $\mathrm{C}_{4}$ PEPC is quite sensitive to sub-optimal temperatures compared to the PEPC of $\mathrm{C}_{3}$ species.

The sharp increase in the activity of PEPC with temperature, particularly above $15^{\circ} \mathrm{C}$, could be physiologically significant, as the temperature is expected to rise from about 10 to $15^{\circ} \mathrm{C}$ in the morning to 35 to $40^{\circ} \mathrm{C}$ at midday, on a typically clear and sunny day. The maintenance of high enzyme activity at warm temperatures, together with a sharp decrease in the malate sensitivity of PEPC was also noticed in other $\mathrm{C}_{4}$ plants [24]. A combination of light and warm temperature could amplify the photoactivation of the PEPC, as observed in case of Egeria densa [30] and Amaranthus paniculatus [20]. The marked reversibility of the effect of temperature on PEPC in case of both $\mathrm{C}_{4}$ and $\mathrm{C}_{3}$ plants [24] is an additional indication of the possible physiological relevance of temperature effects on PEPC.

These results demonstrate clearly the marked changes induced by temperature in the sensitivity of PEPC to malate. As the temperature was raised from $15{ }^{\circ} \mathrm{Cto} 50{ }^{\circ} \mathrm{C}$, there was a marked decrease in malate sensitivity of PEPC. The extent of such a decrease in $\mathrm{C}_{4}$ plants $(79 \%$ to $46 \%)$ was more than that in C3 species (59\% to 29\%) (Figure 2). Thus, PEPC appeared to be highly sensitive to malate at cold temperatures, while becoming relatively insensitive to malate at warm temperatures. The extent of malate inhibition is quite high in L. esculentum compared with A. pungens. Again the limited reports in the literature had conflicting observations. At low temperature, the sensitivity of PEPC to malate was very high in maize [31], but was quite low in Bryophyllum fedtschenkoi [32]. Lowering the temperature from $25{ }^{\circ} \mathrm{C}$ to $3{ }^{\circ} \mathrm{C}$ not only decreased the catalytic capacity of PEPC, but also caused a considerable reduction (about 10fold) in the sensitivity of PEPC to malate [32].

The decrease in malate sensitivity of PEPC can also occur due to the proteolysis of the enzyme. However, the authors are confident that this is not the reason during these observations. There was no detectable change in the protein levels as indicated by the western blots [24]. The changes in activity of PEPC due to temperature were reversible to a marked extent [24].

Arrhenius plots revealed differences between not only the $\mathrm{C}_{3}$ and $\mathrm{C}_{4}$ plants, but also the pattern in presence or absence of malate (Figure 3 ( $\mathrm{a}$ and $\mathrm{b}$ )). As the temperature was raised, the activation energy was lowered in both A. pungens $\left(\mathrm{C}_{4}\right.$ plant) and in $L$. esculentum $\left(\mathrm{C}_{3}\right.$ species $)$. The changes in activation energy as indicated by discontinuities ("breakpoints") in Arrhenius plots at a critical temperature can be an indication of the cold lability of PEPC from different species [23, 33-34]. The break at $27^{\circ} \mathrm{C}$ in case of $\mathrm{C}_{3}$ plants suggests that the $\mathrm{C}_{3}$ enzyme does not respond much to temperatures, above $27^{\circ} \mathrm{C}$. In contrast, the absence of such break and the continuation of slope indicate that the activation energy continues to decrease for $\mathrm{C}_{4}$-PEPC as the temperature rises from $27^{\circ} \mathrm{C}$ to $45^{\circ} \mathrm{C}$. The presence of malate increased significantly the activation energy in both $\mathrm{C}_{3}$ and $\mathrm{C}_{4}$ species (Table 1). Such increase in activation energy of PEPC in presence of malate, an inhibitor, is logical as malate being an effective inhibitor may slow down the thermodynamic responses of PEPC. But in presence of malate the activation energy increased nearly two-fold over that in the absence of malate, during the temperature range of $10^{\circ} \mathrm{C}$ to $27^{\circ} \mathrm{C}$ in both A. pungens and L. esculentum. The limited studies made earlier on the activation energy of PEPC again were conflicting. Some of the reports indicate discontinuity in the Arrhenius plots of PEPC [19] while others did not observe such break points [18].

Table 1. Activation energy ( $\mathrm{kcal} \mathrm{mol}^{-1}$ ) of PEPC in extracts from leaf discs of Alternanthera pungens $\left(C_{4}\right.$ plant) or Lycopersicon esculentum $\left(C_{3}\right.$ species) exposed to different temperatures.

\begin{tabular}{lll}
\hline Temperature range $\left({ }^{\mathbf{0}} \mathbf{C}\right)$ & Alternanthera pungens $\left(\mathbf{C}_{\mathbf{4}}\right.$ plant $)$ & Lycopersicon esculentum $\left(\mathbf{C}_{\mathbf{3}}\right.$ species $)$ \\
\hline Activation energy $\left(\mathbf{k c a l}^{\mathbf{1}} \mathbf{~ m o l}^{-1}\right)$ & & \\
\hline Enzyme activity in the absence of malate & & 18.3 \\
$10-17$ & 13.8 & 9.1 \\
$17-27$ & 3.8 & 1.23 \\
$27-35$ or $27-45^{\text {a }}$ & 2.9 & \\
Enzyme activity in the presence of malate & & 31.0 \\
$10-17$ & 23.0 & 12.5 \\
$17-27$ & 6.1 & 1.03 \\
$27-35$ or $27-45^{\text {a }}$ & 4.5 & \\
\hline
\end{tabular}

${ }^{\text {a }}$ The range was $27-35^{\circ} \mathrm{C}$ for Lycopersicon esculentum and $27-45^{\circ} \mathrm{C}$ for Alternanthera pungens

For Amaranthus cruentus the activation energy rapidly increased below $20^{\circ} \mathrm{C}$, but it is not clear whether it extrapolates to infinity at the same temperature as in Sorghum bicolor, or at a slightly lower temperature [35]. The present data indicates that $\mathrm{C}_{4}$ plants have special adaptation mechanism, which modifies to survive and maintain high rate of photosynthesis under conditions of high temperature. This is to conclude that high temperature tolerance of $\mathrm{C}_{4}$ 
plants is not only the presence of heat shock proteins, but may be a greater part of thermo stability of the carboxylating enzymes. Further, studies are essential to characterize molecular basis of modulation by temperature of PEPC in C4 plants.

\section{Conclusions}

Temperature caused a dramatic modulation of PEPC in leaf discs of Alternanthera pungens $\left(\mathrm{C}_{4}\right)$ compared to that of Lycopersicom esculentum $\left(\mathrm{C}_{3}\right)$. There was a strong contrast in the temperature optima for PEPC activity in leaf discs of Alternanthera pungens and Lycopersicom esculentum. The steep increase in activity of PEPC with rise in temperature could be physiologically significant, as the temperature is expected to rise from about 10 to $15^{\circ} \mathrm{C}$ in the morning to 35 to $40^{\circ} \mathrm{C}$ at midday, on a clear and sunny day. As the temperature was raised, the activation energy was lowered in both Alternanthera pungens and Lycopersicom esculentum. The changes in activation energy as indicated by discontinuities ("breakpoints") in Arrhenius plots at a critical temperature can be an indication of the cold lability of PEPC from different species.

\section{References}

[1] L. Lepiniec, J. Vidal, R. Chollet, P. Gadal and C. Crétin, "Phosphoenolpyruvate carboxylase: Structure, regulation and evolution," Plant Science Vol. 99, 1994, pp. 111-124. doi.org/10.1016/0168-9452(94)90168-6

[2] A. V. Rajagopalan, M. T. Devi and A. S. Raghavendra, "Molecular biology of $\mathrm{C}_{4}$ phosphoenolpyruvate carboxylase: structure, regulation and genetic engineering," Photosynthesis Research, 1994, Vol. 39, pp. 115-135. doi.10.1007/BF00029380

[3] J. Vidal and R. Chollet, (1997) Regulatory phosphorylation of $\mathrm{C}_{4}$ PEP carboxylase. Trends Plant Science, Vol. 2, 1997, pp. 230-237. doi.org/10.1016/S1360-1385(97)89548-9

[4] H. G. Nimmo, "The regulation of phosphoenolpyruvate carboxylase in CAM plants," Trends in Plant Science, Vol. 5, 2000, pp. 75-80. doi.org/10.1016/S1360-1385(99)01543-5

[5] M. Matsuoka, R. T. Furbank, H. Fukayama and M. Miyao, "Molecular engineering of $\mathrm{C}_{4}$ photosynthesis," Annual Review of Plant Physiology and Plant Molecular Biology Vol. 52, 2001, pp. 297-314. doi:10.1146/annurev.arplant.52.1.297

[6] B. Chinthapalli, A. S. Raghavendra, A. R. Rishi and A. Goyal, "Phosphoenolpyruvate carboxylase from $\mathrm{C}_{4}$ plants: Properties and regulation," In: A. Goyal, S. L. Mehta, M. L. Lodha, Eds., Reviews in Plant Biochemistry and Biotechnology, New Delhi, Vol. 1, 2002, pp. 143-160

[7] J. Vidal, S. Coursol and J-N. Pierre, "Reversible phosphorylation in the regulation of photosynthetic phosphoenolpyruvate carboxylase in $\mathrm{C}_{4}$ plants," In: E-M. Aro and B. Andersson, Eds., Advances in Photosynthesis and Respiration, "Regulation of Photosynthesis." Kluwer Academic Publishers, The Netherlands, Vol. 11, 2002, pp. 363-375
[8] Y. Kai, H. Matsumura and K. Izui, "Phosphoenolpyruvate carboxylase: three-dimensional structure and molecular mechanisms," Archives of Biochemistry and Biophysics, Vol. 414 , 2003, pp. 170-179. doi.org/10.1016/S00039861(03)00170-X

[9] P Svensson, O. E. Bläsing and P. Westhoff, "Evolution of $\mathrm{C}_{4}$ phosphoenolpyruvate carboxylase," Achieves Biochemistry Biophysics, Vol. 414, 2003, 180-188. doi.org/10.1016/S00039861(03)00165-6

[10] J. Murmu, B. Chinthapalli and A. S. Raghavendra, "Phosphoenolpyruvate carboxylase from leaves of C4 plants: Biochemistry and molecular biology of regulation," Indian Journal of Plant Physiology, Special Issue, 2003, pp. 164-173.

[11] T. Sugiyama, M. R. Schmitt, S. B. Ku and G. E. Edwards, "Differences in cold liability of pyruvate, Pi dikinase among $\mathrm{C}_{4}$ species," Plant Cell Physiology Vol. 20, 1979, pp. 965-971

[12] J. A. Berry and O. Björkman, "Photosynthetic responses and adaptation to temperature in higher plants," Annual Review of Plant Physiology, Vol. 31, 1980, pp. 491-543. doi:10.1146/annurev.pp.31.060180.002423

[13] S. P. Long, "Environmental responses," In: R. F. Sage and R. K. Monson, Eds., "C $\mathrm{C}_{4}$ Plant Biology," Academic Press, San Diego, 1999, pp. 215-249

[14] C. Potvin and J. P. Simon, "The evolution of cold temperature adaptation among population of a widely distributed $\mathrm{C}_{4}$ weed: barnyard grass," Evolutionary Trends in Plants, Vol. 4, 1990, 98-105

[15] J. N. Burnell, "A comparative study of the cold sensitivity of pyruvate Pi dikinase in Flaveria species," Plant Cell Physiology, Vol. 31, 1990, pp. 295-297. doi.10.1007/BF00037024

[16] Y-C. Du, A. Nose and K. Wasano, "Thermal characteristics of $\mathrm{C}_{4}$ photosynthetic enzymes from leaves of three sugarcane species differing in cold sensitivity," Plant Cell Physiology, Vol. 40, 1999a, pp. 298-304

[17] J. P. Krall, G. E. Edwards and C. S. Andreo, "Protection of pyruvate, Pi dikinase from maize against cold liability by compatible solutes," Plant Physiology, Vol. 89, pp. 280-285. doi:10.1104/pp.89.1.280

[18] Y-C. Du, A. Nose and K. Wasano, "Effects of chilling temperature on photosynthetic rates, photosynthetic enzyme activities and metabolite levels in three sugarcane species," Plant Cell Environment, Vol. 22, 1999b, pp. 317-324. doi:10.1046/j.1365-3040.1999.00415.x

[19] P. J. Phillips and J. R. McWilliam, "Thermal responses of the primary carboxylating enzymes from $\mathrm{C}_{3}$ and $\mathrm{C}_{4}$ plants adapted to contrasting temperature environments," In: M. D. Hatch, C. B. Osmond and R. O. Slatyer, Eds., "Photosynthesis and Photorespiration," Wiley-Interscience, New York 1971, pp. 97-104.

[20] E. Selinioti, Y. Manetas and N. A. Gavalas, "Cooperative effects of light and temperature on the activity of phosphoenolpyruvate carboxylase from Amaranthus paniculatus L.," Plant Physiology Vol. 82, 1986, pp. 518-522. doi.org/10.1104/pp.82.2.518

[21] J. P. Krall and G. E. Edwards, "PEP carboxylase from two $\mathrm{C}_{4}$ species of Panicum with markedly different, susceptibilities to cold inactivation," Plant cell Physiology, Vol. 34, 1993, pp. 111 
[22] R. Chollet, J. Vidal and M. H. O'Leary, "Phosphoenolpyruvate carboxylase: a ubiquitous, highly regulated enzyme in plants," Annual Review of Plant Physiology and Plant Molecular Biology, Vol. 47, 1996, pp. 273-298. doi:10.1146/annurev.arplant.47.1.273

[23] K. Parvathi, A. S. Bhagwat, Y. Ueno, K. Izui and A. S. Raghavendra, "Illumination increases the affinity of phosphoenolpyruvate carboxylase to bicarbonate in leaves of a $\mathrm{C}_{4}$ plant, Amaranthus hypochondriacus," Plant Cell Physiology, Vol. 41, 2000, pp. 905-910. doi:10.1093/pcp/pcd012

[24] B. Chinthapalli, J. Murmu and A. S. Raghavendra, "Dramatic difference in the responses of phosphoenolpyruvate carboxylase to temperature in leaves of $\mathrm{C}_{3}$ and $\mathrm{C}_{4}$ plants," Journal of Experimental Botany, Vol. 54, pp. 707-14. doi:10.1093/jxb/erg078

[25] K. Izui, H. Matsumura, T. Furumoto and Y. Kai, "Phospho enolpyruvate carboxylase: a new era of structural biology," Annual Reviews of Plant Biology, Vol. 55, 2004, pp. 69-84. doi.10.1146/annurev.arplant.55.031903.141619

[26] J. N. Pierre, J. L. Preito, P. Gadal and J. Vidal, "In situ C4 phosphoenolpyruvate carboxylase activity and kinetic properties in isolated Digitaria sanguinalis mesophyll cells," Photosynthesis Research, Vol. 79, 2004, pp. 349355.doi.10.1023/B:PRES.0000017179.31351.f0

[27] G. Grammatikopoulos and Y. Manetas, "Diurnal changes in phosphoenolpyruvate carboxylase and pyruvate, orthophosphate dikinase properties in the natural environment: interplay of light and temperature in a C4 thermophile," Physiologia Plantarum, Vol. 80, 1990, 593-597. doi: 10.1111/j.1399-3054.1990.tb05683.x

[28] K. U. Avasthi, K. Izui and A. S. Raghavendra, "Interplay of light and temperature during the in planta modulation of $\mathrm{C} 4$ phosphoenolpyruvate carboxylase from the leaves of Amaranthus hypochondriacus L.: diurnal and seasonal effects manifested at molecular levels," Journal of Experimental Botany, Vol. 62, No. 3, 2011, pp. 1017-1026. doi:10.1093/jxb/erq333

[29] D. I. Arnon, "Copper enzymes in isolated chloroplasts. Polyphenol oxidase in Beta vulgaris," Plant Physiology, Vol. 24, 1949, 1-15. doi.org/10.1104/pp.24.1.1

[30] P. Casati, M. V. Lara and C. S. Andreo, "Induction of a $\mathrm{C}_{4}$ like mechanism of $\mathrm{CO}_{2}$ fixation in Egeria densa, a submerged aquatic species," Plant Physiology, Vol. 123, 2000, pp. 16111621. doi.org/10.1104/pp.123.4.1611

[31] P. J. Carter, M. B. Wilkins, H. G. Nimmo and C. A. Fewson, "Effects of temperature on the activity of phosphoenolpyruvate carboxylase and on the control of $\mathrm{CO}_{2}$ fixation in Bryophyllum fedtschenkoi," Planta, Vol. 196, 1995, pp. 375-380. doi.10.1007/BF00201398

[32] M-X. Wu and R. T. Wedding, "Temperature effects on phosphoenolpyruvate carboxylase from a CAM and a $\mathrm{C}_{4}$ plant. A comparative study," Plant Physiology, Vol. 85. 1987, pp. 497-501. doi.org/10.1104/pp.85.2.497

[33] J. R. McWilliam and P. J. Ferrar, "Photosynthetic adaptation of higher plants to thermal stress," In: RL Bieleski, A. R. Ferguson, M. M. Cresswell, Eds., "Mechanisms of Regulation of Plant Growth," Bulletin 12, Royal Society of New Zealand, Wellington, 1974, pp. 467-476.

[34] D. Graham, D. G. Hockley and B. D. Patterson, "Temperature effects on phosphoenolpyruvate carboxylase from chillingsensitive and chilling resistant plants," In: J. M. Lyons, J. K. Raison Eds., "Low Temperature Stress in Crop Plants. The Role of the Membrane," Academic Press, New York, 1979, pp. 187-202.

[35] A. Laisk and G. E. Edwards, "CO2 and temperature-dependent induction in $\mathrm{C} 4$ photosynthesis: an approach to the hierarchy of rate-limiting processes," Australian Journal Plant Physiology, Vol. 24, 1997, pp. 505-516. doi:10.1071/PP97011 